University of Wollongong

Research Online

Faculty of Law, Humanities and the Arts Papers (Archive)

$1-1-2018$

\title{
Shades of blue: what do competing interpretations of the Blue Economy mean for oceans governance?
}

Michelle A. Voyer

University of Wollongong, mvoyer@uow.edu.au

Genevieve Quirk

University of Wollongong, gcq691@uowmail.edu.au

Alistair Mcllgorm

University of Wollongong, amcilgor@uow.edu.au

Kamal Azmi

University of Wollongong, kya552@uowmail.edu.au

Follow this and additional works at: https://ro.uow.edu.au/lhapapers

Part of the Arts and Humanities Commons, and the Law Commons

Research Online is the open access institutional repository for the University of Wollongong. For further information contact the UOW Library: research-pubs@uow.edu.au 


\title{
Shades of blue: what do competing interpretations of the Blue Economy mean for oceans governance?
}

\author{
Abstract \\ The 'Blue Economy' is an increasingly popular term in modern marine and ocean governance. The \\ concept seeks to marry ocean-based development opportunities with environmental stewardship and \\ protection. Yet different actors are co-opting this term in competing, and often conflicting ways. Four \\ conceptual interpretations of the Blue Economy are identified, through examination of dominant \\ discourses within international Blue Economy policy documents and key 'grey' literature. The way the Blue \\ Economy is enacted is also examined, through an analysis of the Blue Economy 'in practice', and the \\ actors involved. Finally, the scope of the Blue Economy is explored, with a particular focus on which \\ particular marine industries are included or excluded from different conceptualizations. This analysis \\ reveals areas of both consensus and conflict. Areas of consensus reflect the growing trend towards \\ commodification and valuation of nature, the designation and delimitation of spatial boundaries in the \\ oceans and increasing securitization of the world's oceans. Areas of conflict exist most notably around a \\ divergence in opinions over the legitimacy of individual sectors as components of the 'Blue Economy', in \\ particular, carbon-intensive industries like oil and gas, and the emerging industry of deep seabed mining.

\section{Disciplines} \\ Arts and Humanities | Law

\section{Publication Details} \\ M. Voyer, G. Quirk, A. Mcllgorm \& K. Azmi, 'Shades of blue: what do competing interpretations of the Blue \\ Economy mean for oceans governance?' (2018) Online First Journal of Environmental Policy and Planning \\ $1-22$.
}


Shades of Blue: what do competing interpretations of the Blue Economy mean for oceans governance?

\section{Author names and affiliations:}

Dr Michelle Voyer ${ }^{(a)}$

Ms Genevieve Quirk ${ }^{(a)}$

Prof Alistair McIlgorm ${ }^{(a)}$

Mr Kamal Azmi (a)

(a) University of Wollongong

Australian National Centre for Ocean Resources and Security (ANCORS)

Building 233, Innovation Campus

University of Wollongong NSW 2522 Australia

\section{Corresponding Author}

Michelle Voyer

Australian National Centre for Ocean Resources and Security (ANCORS)

Building 233, Innovation Campus

University of Wollongong NSW 2522 Australia

$\mathbf{T}+61242214653 \mid \mathbf{M}+61413945640$

E: mvoyer@uow.edu.au

https://orcid.org/0000-0001-6170-999

Twitter: @michelle_voyer 


\section{Shades of Blue: what do competing interpretations of the Blue}

\section{Economy mean for oceans governance?}

The 'Blue Economy' is an increasingly popular term in modern marine and ocean governance. The concept seeks to marry ocean based development opportunities with environmental stewardship and protection. Yet different actors are co-opting this term in competing, and often conflicting ways. Four conceptual interpretations of the Blue Economy are identified, through examination of dominant discourses within international Blue Economy policy documents and key 'grey' literature. The way the Blue Economy is enacted is also examined, through an analysis of the Blue Economy 'in practice', and the actors involved. Finally, the scope of the Blue Economy is explored, with a particular focus on which particular marine industries are included or excluded from different conceptualisations. This analysis reveals areas of both consensus and conflict. Areas of consensus reflect the growing trend towards commodification and valuation of nature, the designation and delimitation of spatial boundaries in the oceans and increasing securitization of the world's oceans. Areas of conflict exist most notably around a divergence in opinions over the legitimacy of individual sectors as components of the 'Blue Economy', in particular carbon intensive industries like oil and gas, and the emerging industry of deep seabed mining.

Keywords: Blue Economy; Blue Growth; oceans governance; Sustainable Development Goals

\section{Introduction}

Since the adoption of the UN Law of the Sea (UNCLOS) Treaty in 1982, countries around the world have been actively involved in efforts to establish national sovereignty over marine spaces and the resources that are contained within them (Kildow and McIlgorm, 2010). In many cases these marine jurisdictions are significant, occasionally larger than a country's land mass, and contain an array of living and non-living resources. Stagnation of traditional land-based economies, and the depletion of terrestrial resources has resulted in a greater interest in the economic opportunities 
contained within and under the sea (OECD, 2016). Increasingly coastal states are seeking to secure their maritime boundaries and identify and exploit the resources that are contained within them. While maritime trade and commerce is not new, recent trends reflect a shift towards a more planned economy in the oceans, which manages competing uses, allocates 'ownership' and establishes mechanisms and governance systems designed to protect the national assets contained within a state's jurisdiction (Winder and Le Heron, 2017). In areas beyond national jurisdiction - the high seas UN-led negotiations are ongoing in order to determine how deep sea resources should be shared and managed to protect their biodiversity values and create new opportunities for growth (R Warner, 2009). Hence the oceans have become development spaces, which provide increasing opportunities for coastal states, and states with maritime interests, to build and grow their economies (United Nations, 2014).

The increased focus on the oceans as a development space has occurred within the context of heightened recognition of the profound changes to the world's oceans that are currently underway, in response to climate change, overfishing, habitat destruction and pollution. The oceans are therefore often framed in two competing ways - as areas of opportunity, growth and development, as well as threatened and vulnerable spaces in need of protection. The 'Blue Economy' is a term that has emerged in the past decade, and is borne out of some of the inherent conflicts between these two discourses. As a concept it attempts to embrace the opportunities associated with the ocean, whilst recognizing, accounting for and, in some cases, addressing its threats. In this respect it follows its precursor of the 'Green Economy' in its attempts to use capitalist markets to address environmental threats (Arsel and Büscher, 2012; Castree, 2010; Corson, MacDonald, \& Neimark, 2013). It also forms part of the broader sustainable development movement which commenced with the Brundtland Report, and originally 
focused heavily on terrestrial improvements in environmental management (Brundtland, 1987; Eikeset et al., 2018).

Use of the term 'Blue Economy' has been increasing exponentially over the last decade (Mulazzani and Malorgio, 2017). There remain, however, many unanswered questions about the conceptual and practical applications of the emerging, and increasingly influential notion of a Blue Economy. Unravelling some of the competing claims and apparently incongruous interpretations of the concept is critical given the increasing prominence of the term in forums such as the OECD, United Nations Sustainable Development Forum and Food and Agricultural Organisation of the United Nations (Biermann, Kanie, \& Kim, 2017; FAO, 2016; OECD, 2016). The Blue Economy is increasingly playing a central role in negotiations over the future use of the world's oceans, including the progress towards the UN Sustainable Development Goals (SDGs), yet it is unclear as to whether the negotiations are occurring in a common language, or with an adequate understanding of the implications of the competing ways the term is employed and enacted.

A multi-layered analytical approach was employed to examine the interpretation and use of the Blue Economy concept. This analysis builds on the work of Silver, Gray, Campbell, Fairbanks, \& Gruby (2015), who argued that the Blue Economy is an ambiguous concept used in often competing ways by a range of key actors. It also responds to recent critical examination of the Blue Economy by Winder and Le Heron (2017), who articulated the complex ways in which disciplinary understandings of biological and economic processes are influencing the emergence of the Blue Economy in different settings. This research takes up their call for a deeper social science engagement with the concept of the Blue Economy through a content analysis of a 
range of policy documents, conference proceedings and reports relevant to the Blue Economy.

Three distinct, but related research questions were addressed. The first question allowed for the identification of the different 'lenses' through which the Blue Economy is being conceptualised in different settings, and these lenses subsequently informed the remaining research questions. The three research questions were as follows:

1. How is the Blue Economy conceived, or conceptualised by different actors? (Conceiving the Blue Economy): the Blue Economy is understood to be a socially constructed concept, which influences global discourses and mediates negotiations between actors. Therefore the different conceptions or interpretations of the Blue Economy were explored through an examination of the way the term 'Blue Economy' was used in relation to a range of other concepts and ideas.

2. How is the Blue Economy enacted? (Enacting the Blue Economy): the Blue Economy suggests a series of planned actions designed to 'enact' a particular conceptual understanding of the term. This was explored by searching for examples of the Blue Economy concept 'in practice' and the tools used to progress Blue Economy plans and processes.

3. How is the scope of the Blue Economy defined? (Defining the scope of the Blue Economy): the Blue Economy can be understood as a new form of governance which articulates appropriate use and management activities within the oceans, however it remains unclear as to how 'appropriateness' is defined within the bounded nature of the Blue Economy concept. The extent to which the different conceptualizations of the Blue Economy privilege 
particular uses and interests, and competing ideas about its geographical and sectoral 'scope' was subsequently explored.

This analytical approach was designed to inform dialogue between actors of areas of consensus and conflict in relation to the development and implementation of the Blue Economy concept. This approach fills a gap in the academic planning literature by creating a space for this dialogue to occur in the absence of an agreed definition, or a consistent approach to the application of the Blue Economy concept in practice. The paper begins with an initial literature review which summarises existing knowledge in relation to the three research questions. It will then provide some details of the methodological approach before identifying the different ways the Blue Economy is being conceived (or Blue Economy 'lenses'). These lenses are then used to inform the explorations of how the Blue Economy is being enacted, and its scope defined. Finally the paper will conclude by exploring areas of consensus and conflict revealed through the analysis, and the implications for broader ocean governance.

\section{Background}

This section summarises the existing published material related to the three research questions. For the first question, conceiving the Blue Economy, the historical emergence of the term is explored as well as some of the definitions currently in circulation. Existing knowledge in relation to the interaction between the Blue Economy and other ocean governance tools is summarised for the second question - enacting the Blue Economy. The final section - defining the scope of the Blue Economy - explores the relationship between the Blue Economy and the ocean and coastal economy, and incorporates consideration of both geographical and sectoral scope. 


\section{Conceiving the Blue Economy}

The historical development of the concept of a 'Blue Economy' provides insights into the different ways in which the term has been constructed and used by different actors. The term 'Blue Economy' first emerged during the 2012 United Nations Convention on Sustainable Development (UNCSD), or Rio+20 conference, however, its roots lie in the earlier 1992 Rio Earth Summit. This summit, building on the earlier Brundtland report, recognized the importance of development which accounted for the needs of future generations (Brundtland, 1987). It focused on fostering the growth of a 'Green Economy', later defined as an economy “that results in improved human well-being and social equity, while significantly reducing environmental risks and ecological scarcities" (UNEP, 2011 p16). In response to an international push to 'green' the global economy, Small Island Developing States (SIDS) began emphasizing the importance of the ocean and marine economy, promoting the concept of a Blue Economy (Silver, et al., 2015; Whisnant and Reyes, 2015). Since that time there has been increasing interest in the Blue Economy around the world, yet there is no accepted definition of the Blue Economy (Choi, 2017; Eikeset, et al., 2018; Silver, et al., 2015; Winder and Le Heron, 2017).

In a concept paper published in 2014 the United Nations define the Blue Economy as an ocean economy that aims at the "improvement of human well-being and social equity, while significantly reducing environmental risks and ecological scarcities." (UNCTAD, 2014 p2). The World Wildlife Fund (2015) define the Blue economy as a marine based economy that:

- Provides social and economic benefits for current and future generations, by contributing to food security, poverty eradication, livelihoods, income, employment, health, safety, equity, and political stability. 
- Restores, protects and maintains the diversity, productivity, resilience, core functions, and intrinsic value of marine ecosystems - the natural capital upon which its prosperity depends.

- Is based on clean technologies, renewable energy, and circular material flows to secure economic and social stability over time, while keeping within the limits of one planet.(WWF Baltic Ecoregion Programme, 2015 p1)

In 2008-09 a Partnership for the Environmental Management of the Seas of the East Asia (PEMSEA) project culminated in the establishment of the Changwon Declaration, which defined the Blue Economy as:

a practical ocean-based economic model using green infrastructure and technologies, innovative financing mechanisms and proactive institutional arrangements for meeting the twin goals of protecting our oceans and coasts and enhancing its potential contribution to sustainable development, including improving human well-being, and reducing environmental risks and ecological scarcities. (Whisnant and Reyes, 2015 p25)

Other definitions of the Blue Economy or Blue Growth have been established by the World Oceans Council, the Australian Government, the Indian Ocean Rim Association, the European Union and The Economist magazine (Mohanty, Dash, Gupta, \& Gaur, 2015; National Marine Science Committee, 2015; The Economist, 2015; Whisnant and Reyes, 2015). Most definitions include a focus on 'triple bottom line objectives' of environmental sustainability, economic growth and social equity, driven by an integrated oceans governance approach and technological innovation (Keen, Schwarz, \& Wini-Simeon, 2017; Smith-Godfrey, 2016)

Perhaps the one universally agreed aspect of the Blue Economy is that it is a fluid concept, employed differently in different contexts and by different actors (Choi, 2017; Eikeset, et al., 2018; Silver, et al., 2015; Winder and Le Heron, 2017). An analysis of the way the term was employed as part of the Rio +20 Earth Summit 
proceedings was conducted by Silver, et al. (2015), and highlights the way the Blue Economy was a concept employed by various groups within the negotiation process to prosecute particular ideas and actions. Four dominant discourses were identified:

(1) Oceans as natural capital: predominately employed by environmental NGOs who used the term as a means of arguing that ecosystem services provided by marine environments should be better recognized and accounted for.

(2) Oceans as good business: promoted by marine sectors such as fisheries and shipping as well as development agencies, this theme called for greater recognition of the ocean based industries and the contribution they make to society.

(3) Oceans as integral to Pacific SIDS: Pacific SIDS were actively engaged in framing the Blue Economy around their livelihoods and development objectives.

(4) Oceans as Small-Scale Fisheries (SSF) livelihoods: this theme focused on poverty reduction and role of SSF in providing a source of protein and livelihoods for the world's poor. It was largely promoted by SSF organizations and advocates, including development organizations and SIDS. (Silver, et al., 2015)

The vast differences in interpretations of the Blue Economy demonstrated in the Silver, et al. (2015) study suggests that understanding of the concept is unlikely to be completely resolved through an agreed definition. In fact, consensus over a universal definition may be unlikely given the inherent conflicts that exist between the different ways the term is understood. Ambiguity is not, however, unusual within policy settings. Terms such as the Blue Economy can be understood to be 'buzz words' (Bowen and Fankhauser, 2011; Choi, 2017). These are terms which 'represent a general agreement in the abstract, but they generate endless (and irresolvable) disagreements about what 
they might mean in practice' (Bueger, 2015 p160). It is difficult to find consensus on the definition of such buzzwords precisely because different actors will favour particular interpretations which meet their own purposes. While this can be problematic it can also 'allow actors to coordinate their action and proceed in joint activities while simultaneously disagreeing over local meanings' (Bueger, 2015 p160). Silver, et al. (2015) demonstrates that the ambiguity of the term 'Blue Economy' has been embraced by some actors as they seek to co-opt it to support negotiations over management and use, by highlighting and promoting their own interpretations of the term. In particular, some SIDs (such as Seychelles) have been particular champions of the notion of a Blue Economy, reframing their place in global economies as 'Large Ocean States'. The Blue Economy has provided them a greater role at the negotiating table and repositioned SIDS as areas of opportunity, in contrast to common messages received about these states as economically depressed, victims of climate change (Dreher and Voyer, 2015).

\section{Enacting the Blue Economy}

To date the Blue Economy as a concept can be seen to be consistent with recent broader trends in environmental management in its evolution from 'triple bottom line' objectives of environmental sustainability, economic development and social equity or inclusiveness (Keen, et al., 2017). It also interacts in complex and opaque ways with a broad suite of other ocean governance tools such as Marine Spatial Planning (MSP), Ecosystem Based Management (EBM) and Integrated Coastal Management (ICM); which themselves are often poorly defined and ambiguous concepts (Bueger, 2015; Engler, 2015). Unlike these governance tools, however, the Blue Economy lacks established frameworks, guidelines or toolkits through which objectives can be developed, action plans implemented and assessment and monitoring programs devised. This has been linked by some to the lack of an agreed, and universally accepted 
definition to underpin these governance frameworks (WWF Baltic Ecoregion Programme, 2015). Others reject the need for a universal definition and call for jurisdictions to develop their own Blue Economy agendas based on the specific needs of their constituency (Michel, 2016). In the absence of a definition, many actors have progressed Blue Economy 'actions'. Whilst acknowledging the inherent ambiguity of the term these activities have focused on 'operationalizing' or enacting the Blue Economy (Greenhill, Hughes, Day, \& Stanley, 2015; Keen, et al., 2017).

Important insights can be derived through an examination of the tools and techniques used to enact a Blue Economy. These activities guide and influence the behaviour of actors, privileging and promoting some actions, and actors, whilst disincentivizing others. Winder and Le Heron (2017), for example, argue that European Commission's expression of the Blue Economy recruits economic development and assessment activities such as valuation studies, regional development and innovation, at the expense of a more complete understanding of the biological, and geographical components of these projects.

Concerns have been raised in both the Green and Blue economy literature about how this rhetoric has been used in practice to justify and facilitate land (or ocean) grabbing, displacement of Indigenous people and other activities at odds with sustainability objectives (Anderson, Kusters, McCarthy, \& Obidzinski, 2016; Bennett, Govan, \& Satterfield, 2015; Brockington and Ponte, 2015). Green growth paradigms have also been critiqued as contributing to a broader trend toward the neoliberalization of nature, through an emphasis on privatization and marketization or commodification of nature (Castree, 2010). The extent to which the Blue Economy is contributing to these same trends remains largely unexplored. 


\section{Defining the scope of the Blue Economy}

The Blue Economy is emerging as a new governance tool which is used to articulate appropriate use within the oceans at global, regional and national scales. In addition to the lack of a clear definition, there is also significant ambiguity around the extent of the governance 'reach' of a Blue Economy. This relates to the geographic scale of the concept - does the Blue Economy incorporate coastal or deep sea environments, or both? How does the Blue Economy interact with land based systems? Questions of scale also apply to sectors, especially in relation to which industries or individual businesses can be considered to be a part of a Blue Economy and which cannot.

Existing definitions of the Blue Economy point to an ambiguous affiliation between the Blue Economy and the related concepts of an 'ocean economy' and 'coastal economy'. Whilst definitions of the Blue Economy vary (as outlined previously), there is consensus in relation to what constitutes an 'ocean economy', which is described as;

'that portion of the economy which relies on the ocean as an input to the production process or which, by virtue of geographic location, takes place on or under the ocean' (Kildow and Mcllgorm, 2010 p368).

The ocean economy (also sometimes referred to as the marine economy) is distinct from, but a portion of the coastal economy, which incorporates all economic activity that occurs on or near the coast (C. Colgan, 2003; Kildow and McIlgorm, 2010; Mohanty, et al., 2015).

The interaction between the ocean, coastal and Blue Economies is less well established. A key difference between the terms is that while the ocean and coastal economies are seen as an aggregation of a range of individual businesses and sectors, the focus of the Blue Economy is on integrated management, which aims to manage across sectors, across geographical scales and across the land - ocean interface. Despite 
this, it is common for the Blue Economy to be linked to these concepts, and in particular the ocean economy, given its distinct focus on marine industries. Table 1 details the main sectors considered as being associated with the 'ocean economy', and 'taxonomies' such as this one are often associated with any discussion of the Blue Economy (Kildow and McIlgorm, 2010; Alistair McIlgorm, 2005; The Economist, 2015).

\section{INSERT TABLE 1}

Defining the scope, or conceptual boundaries of a Blue Economy remains underdeveloped but is likely to be of critical future importance. A common critique of the Green Economy is the ability for it to be used as a tool to legitimize and conceal less than ethical or environmentally responsible behaviour or uses, through 'greenwashing' (Johansen, 2015; Lightfoot and Burchell, 2004; Marquis). Identifying and defining what practices, sectors or businesses are considered 'green' (or 'blue') are therefore central to the legitimacy of Blue Economy as a concept and public confidence in associated actions.

\section{Methods}

The primary method employed to address the three research questions was a content analysis of available 'grey' literature which contained explicit reference to 'Blue Economy', 'Blue Growth' or terms such as 'Greening the Ocean Economy'. The methods followed from Bueger (2015) in using a three pronged approach to examining a governance 'buzzword'. This involved examining three important facets of the Blue Economy: the way the term is used in relation to other concepts and ideas (conceiving the Blue Economy), the Blue Economy in practice (enacting the Blue Economy) and the 'bounded' nature of the term in terms of what is considered to be 'in' and 'out' of the Blue Economy (defining the scope of the Blue Economy). 
The literature examined largely took the form of policy documents, conference proceedings, position papers and reports, and was obtained through three primary means:

- A general web search using the term 'Blue Economy' and 'Blue Growth',

- A targeted web search of known agencies, organizations and NGOs engaged in Blue Economy activities (e.g. the European Commission, OECD etc.), and

- A targeted search via key Government and academic contacts working in the field of the Blue Economy.

A list of the key documents is contained in Table 2. It is acknowledged that there are gaps in this list, given the difficulties associated with obtaining grey literature, which is often not publically available or readily accessible. This is particularly true for developing regions such as Africa, where web based sources are not always available. In addition, language is also likely to have placed significant restrictions on access to some highly relevant documentation. For example, China is known to have an active Blue Economy agenda, however there are limited reports or policy documents available to the public, or in English. This should not, therefore, be considered an exhaustive list, but rather reflects a concerted effort to reflect prominent and influential Blue Economy grey literature from as many different regions of the world as possible. In total 37 documents were included in the analysis. In order to address the recognized gaps in this study, the findings are supported where possible by a review of published academic literature from scholars studying the emergence of Blue Economy in China and other areas.

INSERT TABLE 2

The ways in which different actors conceived of or employed the term 'Blue Economy' 
in the various pieces of literature was explored using a content analysis. This involved repeated coding and sorting of dominant themes or ideas found within executive summaries and introductions of each document. An initial thematic analysis identified five overarching themes within the Blue Economy grey literature, consistent with the primary objectives of the Blue Economy identified by Keen, et al. (2017); economic, environmental, social, innovation and technical capacity, and governance tools or approaches. These themes provided a framework by which to further identify, collate and categorize key phrases and concepts (or sub-themes) contained within the literature. These sub-themes were identified through recurrent trends of ideas or key phrases which commonly occurred across the range of documents. A list of the primary subthemes identified through this analysis is contained in Table 3.

\section{INSERT TABLE 3}

A cluster analysis was then conducted in order to identify the co-occurrence of key themes. This was conducted through NVIVO11 software, using a Pearson's correlation co-efficient. This process groups items that are coded similarly using a hierarchical clustering algorithm and allows for a representation of similarity between 'nodes' (in this case the identified sub-themes). The themes 'innovation' and 'blue economic growth' were excluded from the analysis given their near universal inclusion within the literature. The findings of this analysis found four dominant 'groupings' or clusters of terms as they occurred within the literature. These clusters were refined and validated through more detailed qualitative analysis of the main body of the documents, as well as a comparison with the discourses identified by Silver, et al. (2015) and the broader scholarship on the Blue Economy.

The results of this analysis - which formed the basis of the methodological examination of the first research question (conceiving the Blue Economy) - were 
subsequently used to examine the remaining two research questions (enacting the Blue Economy and defining the scope of the Blue Economy). 'Enacting the Blue Economy' involved a more detailed examination of the primary governance tools associated with each of the four identified lenses, supplemented with a qualitative analysis of the body of the documents outlined in Table 2 and a range of other primary literature. 'Defining the scope of the Blue Economy' was a qualitative analysis, involving an examination of if and how sectoral and geographic boundaries of the Blue Economy were defined. Whilst the majority of the literature is largely silent on this topic, there are some 'clues' on the level of acceptance of the full suite of ocean industries under the Blue Economy umbrella in the different definitions and approaches adopted by different actors. These definitions, and broader report content was therefore used to surmise a position in relation to geographical and sectoral scope.

\section{Results}

\section{Conceiving the Blue Economy}

This first research question explored the different ways the Blue Economy of being conceived by different actors or in different settings. The cluster analysis identified four clusters, or lenses, through which the Blue Economy is currently articulated. Figure 1 contains a matrix highlighting these four lenses and how related concepts and ideas interacted with them.

\section{INSERT FIGURE 1}

The combination of the cluster analysis and the qualitative validation revealed that, as illustrated in Table 3, many sub-themes were common across a large number of documents analysed, and that these sub-themes were usually not exclusive to one particular lens. In fact, sub-themes might be seen across all four lenses and, in addition, 
elements of all four lenses might be seen within a single policy document. In particular the themes of 'Marine Spatial Planning' and 'maritime security' appeared to be significant across all four interpretations. Most documents, however, tended to prioritize or privilege one or two of the identified lenses. In particular there was a close relationship between the 'oceans as natural capital' and 'oceans as livelihood' lenses and, similarly, between the 'oceans as good business' and 'oceans as a driver of innovation' lenses, as explained in greater detail in the following sections.

\section{Lens 1: Oceans as Natural Capital}

The first lens was titled 'oceans as natural capital' in recognition of the similarities with the discourse identified by Silver, et al. (2015) of the same name. It indicated the cooccurrence of a range of sub-themes relating to environmental protection and restoration, MPAs, EBM, de-carbonization and climate change mitigation and community wellbeing. Whilst environmental protection and sustainability are fundamental to most interpretations of the Blue Economy, the key focus of this body of literature was prioritization of these aspects of sustainable development, alongside human health and wellbeing. An exemplar of this approach is the World Wildlife Fund (WWF), which clearly foregrounds environmental objectives in their definition of the Blue Economy.

\section{Lens 2: Oceans as Livelihoods}

The second lens, termed 'oceans as livelihoods', was aligned with the Silver, et al. (2015) themes of 'Oceans as Integral to Pacific SIDS' and 'Oceans as Small-Scale Fisheries Livelihoods'. The cluster analysis indicated a co-occurrence of human health and safety sub-themes, including themes relating to livelihoods, food security, poverty alleviation and income and employment generation. The literature that favoured this 
interpretation of the Blue Economy most commonly included documents developed by development organizations and countries in the Global South, in particular, SIDS in the Indian and Pacific Oceans and the Caribbean (Keen, et al., 2017; Michel, 2016; Patil, Virdin, Diez, Roberts, \& Singh, 2016; Purvis, 2015). This lens was also the most likely to include reference to the importance of understanding and acknowledging traditional ecological knowledge and cultural practices, although this did not emerge as a strong theme in any of the documents analysed.

Other key proponents of this interpretation of the Blue Economy include organizations such as the Food and Agriculture Organization (FAO, 2014a, 2016; Global Oceans Action Summit, 2014), who particularly focus on the link between global food security and the Blue Economy. This lens highlights the potential of the Blue Economy as a means through which the contributions of small scale fisheries and other smaller scale economic sectors can be accounted for and considered.

A more recent trend in the literature on the Blue Economy from development organizations is the emphasis on clear links between the Blue Economy and the UN SDGs, particularly SDG 14 (life below water)(National Maritime Foundation, 2017; Patil, et al., 2016; Roberts and Ali, 2016).

\section{Lens 3: Oceans as Good Business}

The third lens, indicated the co-occurrence of a range of 'sub themes' relating to the classification of component sectors of a Blue Economy, the valuation of those sectors and the identification of sector-specific growth strategies. This body of literature sometimes referred to the development of 'maritime clusters', which refers to the geographic concentrations of interconnected companies and institutions around particular maritime industries (European Commission, 2012a; OECD, 2016). The focus on economic development and growth within this lens is consistent with the 'oceans as 
good business' discourse identified by Silver, et al. (2015), and hence the same categorization was adopted.

Documents that demonstrate the key features of this lens included literature from larger economies and organizations which represent those states, including the European Commission, OECD and industry and business groups. The primary focus of this interpretation appears to be securing economic growth from the oceans, in a manner which is sensitive to environmental constraints. Many of the documents relevant to this lens therefore primarily focus on quantifying the benefits provided by existing marine sectors and developing projections and strategies for future growth (ECORYS Nederland BV, 2012; European Commission, 2012a, 2014; Gulf Coast Community Foundation, 2015; The Economist, 2015). For example, the OECD report 'The Ocean Economy in 2030' (OECD, 2016) identifies ocean industries as a key driver of global economic growth over the next decade.

Looking to 2030, many ocean-based industries have the potential to outperform the growth of the global economy as a whole, both in terms of value added and employment. The projections suggest that between 2010 and 2030 on a "businessas-usual" scenario basis, the ocean economy could more than double its contribution to global value added, reaching over USD 3 trillion. (OECD, 2016 p1)

\section{Lens 4: Oceans as a Driver of Innovation}

The final lens identified the co-occurrence of sub-themes relating to investment, innovative financing and private sector involvement in blue growth strategies. These themes focused on an interpretation of the Blue Economy as a 'driver of innovation' with a primary focus on developing new ways of using the ocean - by changing our approach to 'old' industries like fisheries, or by coming up with entirely new uses, like marine biotechnology, ocean based renewables or deep sea mining. The 'Oceans as 
good business' and 'Oceans as a driver of innovation' lenses are closely related, as innovation, investment and public/private sector partnerships are seen as key drivers of the success of 'Blue Growth' strategies. For example, research and development is seen as central to the European vision of Blue Growth:

\footnotetext{
New sources of growth are triggered by continuous innovation. At the same time innovation activates labor productivity improvements which have a direct impact on economic growth. Hence research, development and innovation are at the heart of any Blue Growth strategic framework.(ECORYS Nederland BV, 2012 p22)
}

An example of a document which emphasizes this Blue Economy lens includes the Australian National Marine Science Plan (NMSP). This plan primarily focuses on the role of the science community in addressing key challenges to the growth of the Australian Blue Economy, and identifies a range of research and development strategies aimed at facilitating this growth (National Marine Science Committee, 2015).

\section{Enacting the Blue Economy}

The second research question explored the way the Blue Economy is being put into practice, or enacted. While the infancy of the Blue Economy as a concept means that there are limited practical examples of its application, insights were uncovered through the analysis of the available literature, with reference to the four lenses identified in the content analysis.

\section{Oceans as natural capital}

No specific 'Blue Economy’ projects were identified which were associated with this lens. The content analysis suggests, however, that for some actors, particularly environmental NGOs, the Blue Economy has provided a means through which environmental objectives and outcomes can be linked with broader economic and 
development narratives. For example, environmental NGOs have used the concept of the Blue Economy to link environmental management objectives and tools, such as MPAs and EBM, to improvements in livelihoods, wellbeing and poverty reduction. In particular, valuation of ecosystem services is promoted within this lens as a key tool to identify and communicate the range of social and economic benefits derived from healthy marine ecosystems.

\section{Oceans as livelihoods}

The practical application of the Blue Economy model in developing states is contextspecific. In some SIDS the focus of the Blue Economy has primarily related to encouraging improvements in management of and community returns from existing economic sectors, especially fisheries. For example, a review of the implementation of Blue Economy projects in the Pacific by Keen, et al. (2017) found that they tended to concentrate on traditional sectors, such as developing improved value chains for fisheries production (Keen, et al., 2017). The strength of the Blue Economy concept in this setting was seen to be as a tool which could link existing environmental management approaches more effectively to the SIDS setting, for example through greater recognition of customary tenure and cultural context, with economic returns to communities still under developed (Keen, et al., 2017).

In Grenada, in the Caribbean Islands, efforts to grow the Blue Economy have included the development of a research institute, a policy framework incorporating MSP and specific project-based actions, particularly in the important economic sectors of fisheries and marine tourism (Patil, et al., 2016). The Blue Growth strategy of the FAO is linked closely with ensuring long term food security through support for small scale fisheries and the development of sustainable aquaculture operations (FAO, 2014a, 2014b, 2016). 
In other settings, the implementation of a Blue Economy has focused primarily on diversification and the identification of new sources of growth for developing states. Seychelles has been particularly active in promoting the development of a Blue Economy through the establishment of a range of governance and research and development mechanisms focusing on diversification, environmental sustainability, the provision of high value jobs and food security (Purvis, 2015).

\section{Oceans as good business}

The 'Blue Growth' strategy developed by the European Commission (EC) is perhaps the most well-known and well established application of the Blue Economy concept. The plans established by the EC are consistent with those of larger economies in that they single out key marine sectors such as aquaculture, deep sea mining, biotechnology and ocean based renewables for the development of specific 'Blue Growth' strategies. These strategies usually involve the development of governance and financing arrangements to secure that growth. MSP also plays an important role in the EC approach to Blue Growth (European Commission, 2012a). MSP in this context aims to give certainty to businesses and investors, resolve resource and user conflict and ensure a strategic approach to the development of ocean spaces. Another key tool employed within this lens is economic valuation in order to identify the worth of ocean based industries to national, regional and global economies.

The private sector has also embraced the 'oceans as good business' lens. Industry groups including the World Ocean Council (WOC) and the Economist Intelligence Unit (EIU) have sought to encourage Blue Economy development through events such as the World Ocean Summit (hosted by the EIU) and the Sustainable Ocean Summit (hosted by the WOC). These events aim to foster greater engagement of the private sector in the sustainable development of the oceans, including by creating 
opportunities and incentives for innovation. They also aim to link business with broader oceans governance fora, such as efforts to reach SDGs, including SDG 14 (Holthus, 2017).

Other large economies, including China and India have embraced the Blue Economy as a source of new economic growth. In China, the Blue Economy has been guided by the development and implementation of Marine Functional Zoning, which has aimed to rationalize governance arrangements, nurture sustainable industries and secure sovereign rights (Choi, 2017; Lu, Liu, Xiang, Song, \& McIlgorm, 2015). In addition, China is prosecuting a significant blue growth agenda, both within and outside its maritime jurisdiction, including through the initiation of its 'Maritime Silk Road' project. This project aims to secure trade routes and open up new economic opportunities in the region, through infrastructure development and associated maritime clusters along significant trade routes in the Indian and Pacific Oceans (Karim, 2015; Walsh, 2017). In particular, the expansion of new and existing port and shipping networks forms a large component of China's Blue Economy agenda (see Khurana, 2016).

\section{Oceans as a driver of innovation}

Innovation is central to many of the interpretations of the Blue Economy. This lens also intersects with the original, but (at least initially) unrelated, conception of the Blue Economy as put forward by Gunter Pauli which champions 'blue sky' thinking and innovation (Pauli, 2010). The significance of research and development to the continued growth of the Blue Economy has been recognized in many developed and developing states though the establishment of research institutes or networks. These institutes are designed to provide a supporting role for Blue Growth through partnerships with industry, and the development of technological advances in resource use and 
management. Examples include the Ocean Enterprise in the United States which aims to provide effective weather observation and forecasting to support for ocean businesses (ERISS Corporation and The Maritime Alliance, 2017). In the Netherlands the Maritime Research Institute Netherlands (MARIN) and Delft University of Technology (TU Delft) provide academic research to support the maritime sector, particularly shipping. Incubators and accelerators for start-ups in the marine sector are also being embraced around the world, with examples including the Buccaneer Delft offshore energy accelerator (Netherlands), the SCRIPPS Venture Partners Program (USA), and the James Michel Foundation Blue Economy Incubator Program (Seychelles).

The innovative approaches championed within the literature are diverse - some are technical or technological advances which will allow more efficient, cost effective and environmentally sensitive resource use. Others relate to management, in particular to innovative financing mechanisms which engage the private sector and secure long term investment in emerging industries (Rustomjee, 2016; Whisnant and Reyes, 2015). For example, novel approaches to financing, such as debt swaps, blue bonds and payments for ecosystems services are being actively pursued by a number of countries in order to secure the necessary funds required to kick start investment in emerging industries (Gordon, Murray, Pendleton, \& Victor, 2011; Patil, et al., 2016; Purvis, 2015; Rustomjee, 2016; Whisnant and Reyes, 2015).

\section{Defining the scope of the Blue Economy}

The final research question focused primarily on the question of the scope of the different conceptual understandings of the Blue Economy approach, considering both geographical and sectoral attributes. There was limited engagement with these questions found within the literature studied and tended to fall into two main categories consistent with two groupings of the identified lenses. 
Both the 'oceans as natural capital' and 'oceans as livelihoods' lenses tend to place a particular emphasis on more traditional and established industries, especially food producing sectors such as fisheries and aquaculture. These lenses also appeared to be more restrictive in relation to the sectors which could be considered to fall within the blanket term of a 'Blue Economy'. In some regards this appears to be a moral question, which implicitly questions the legitimacy of some sectors as 'Blue'. For example, the WWF definition, emphasizes clean technologies, renewable energy and circular flow materials (WWF Baltic Ecoregion Programme, 2015). Fossil fuel-dependent, carbonintensive industries such as the oil and gas sector, whilst not explicitly excluded, are unlikely to meet this definition of a Blue Economy. In addition, deep sea mining is being treated with significant caution by some SIDS, with concerns that the environmental costs of resource extraction might not be consistent with their Blue Economy vision (World Bank and United Nations Department of Economic and Social Affairs, 2017).

The exclusion of these more controversial sectors is not universal, however, and for some the criteria around inclusion or exclusion of sectors are not so much around legitimacy but practicalities. In practice, developing states have been less successful in expanding their Blue Economy activities into larger and emerging industries outside the traditional sectors of fishing and tourism, often due to difficulties in accessing secure finance (Keen, et al., 2017; Roberts and Ali, 2016; Rustomjee, 2016). Some SIDS, such as the Seychelles, are, however, also exploring opportunities that might be provided through deep sea mining and oil and gas (Michel, 2016).

Overall, however, the focus of the 'oceans as livelihood' lens tends towards social enterprise or development of small scale business opportunities which can 
eventually be scaled up to provide enhanced social and economic benefits. For the 'oceans as natural capital' lens, questions of scale largely focus on ecosystem level management approaches, through EBM and other measures, as well as small scale conservation projects.

\section{Oceans as good business/Oceans as a driver of innovation}

The 'oceans as good business' lens generally consider the Blue Economy to be a subset of the ocean economy (C. S. Colgan, 2016) and definitions tend to be broad enough to embrace all ocean-based economic activities. In particular, some of the documents associated primarily with this lens use the terms 'Blue Economy' and 'ocean economy' interchangeably with little distinction drawn between the two terms. In some cases, efforts to develop a Blue Economy begin and end with strategies designed to grow ocean-based industries. The 'oceans as a driver of innovation' lens takes a similar approach but tends to focus most on new and emerging industries, such as marine biotechnology, deep sea mining and renewables.

The focus of the 'oceans as good business' lens tends towards high value sectors, such as shipping, oil and gas and large scale fisheries. In this setting the Blue Economy focuses largely on aggregation and integration across these sectors with the focus on sub-national (through maritime clusters), national and regional level scales. The 'oceans as a source of innovation' naturally lends itself to smaller scale 'start-up' businesses and associated incubators, and therefore tends towards a more local level district or provincial scale.

One of the distinguishing features of these interpretations of the Blue Economy is the focus on valuation studies, which aim to quantify the economic value the ocean economy (C. S. Colgan, 2016; Ebarvia, 2016; Alistair McIlgorm, 2016). In particular, China and other countries within the PEMSEA coalition have been actively working on 
developing a common system of economic valuation based around national income accounts (Corazon Ebarvia and Habito, 2014; East Asian Seas Congress, 2012; Ebarvia, 2016). This process can be understood as a step-by-step program which aims to build a picture of the value of the ocean economy, which can then be used to inform Blue Economy development (Beaudoin and Pendleton, 2012; C. S. Colgan, 2016; Ebarvia, 2016; Kildow and McIlgorm, 2010; Alistair McIlgorm, 2016). The process of moving to a Blue Economy is therefore seen to involve accurate measures of:

(1) the ocean economy,

(2) the natural assets on which the ocean economy is based (i.e ecosystem service valuation), and

(3) the costs of externalities, or the extent to which natural assets are being 'devalued' through unsustainable practices.

This process aims to build a more accurate and complete picture of the true costs and benefits of all ocean uses, including non-market uses, in order to better incorporate and understand sustainability in business development, planning and management (see Mulazzani and Malorgio, 2017 for a more detailed examination of the role of ecosystem accounting frameworks in the transition towards a Blue Economy).

\section{Discussion}

\section{What is the Blue Economy?}

Four main conceptualizations of the term 'Blue Economy' were identified through the analysis, as summarized in Table 4. These lenses have been used across different jurisdictions, geographic scales and actors and demonstrate the malleable way in which the concept has been employed. The findings of this analysis is consistent with the 
outcomes of earlier research conducted by Silver, et al. (2015), in that both studies clearly demonstrate the ambiguities and inherent tensions underpinning the Blue Economy as a concept. This research also highlights that despite the rapid uptake of the concept, there has been little to no clarification of the term or resolution of the competing discourses revealed by Silver, et al. (2015) in their study of the 2012 Rio+20 conference.

\section{INSERT TABLE 4}

The 'oceans as natural capital' lens can largely be seen as the aggregation and reconfiguring of a range of existing conservation management efforts, rather than a new approach to ocean conservation per se. It is demonstrated by a trend towards community based approaches for tools like MPAs and an increased focus on EBM, which inherently recognizes the role of humans in ecological systems (Engler, 2015). This is perhaps the least widely employed variant of the term but has been adopted by environmental NGOs, particularly the WWF, as part of a broader trend towards more socially responsible conservation, and the encouragement of social enterprise (Bush, M. Bottema, Midavaine, \& Carter, 2017; Chaigneau and Brown, 2016; Phelps, Friess, \& Webb, 2012; Robin Warner et al., 2016). The 'oceans as natural capital' lens has allowed conservation actors to adopt the term Blue Economy as a means of articulating the broader suite of objectives they seek to achieve through their activities and speak to broader audience of stakeholders and potential collaborators.

The 'oceans as livelihoods' lens frames the Blue Economy as a tool which can assist in addressing poverty and food security issues and build social and economic resilience in the face of climate change and natural and socio-economic 'shocks', such as natural disasters and economic downturns. Whilst the focus on much of the Blue Economy activity within this lens is on the traditional sectors of fisheries and tourism, 
the importance of diversification is also recognized, with the Blue Economy providing a mechanism through which to expand economic interests beyond these sectors, especially in SIDS and least developed countries (Roberts and Ali, 2016; Rustomjee, 2016). The 'oceans as livelihoods' lens has allowed SIDS and SSF advocates to draw the world's attention to the importance of recognizing their vast marine jurisdictions and the ways in which economic opportunities can be derived from them. These efforts are increasingly being linked to the fulfilment of the United Nations SDGs (Biermann, et al., 2017). Goal 14, 'Life Below Water', specifically addresses issues of relevance to the Blue Economy, but the Blue Economy may also play an important role in addressing other SDGs, including goals relating to poverty alleviation, food security, affordable and clean energy and climate action (Roberts and Ali, 2016).

The 'oceans as good business' lens is favoured by the private sector and the established and emerging world economies including the European Union, China, India and other south-east Asian countries. In most cases the focus of their engagement with the concept of a Blue Economy relates primarily to large, multinational companies in the shipping, industrial fishing, oil and gas and mining sectors, alongside strategies for valuing the contribution of these sectors to national and international economies. In part the scale of these contributions is emphasized to lay stake to the importance of these sectors and their capacity to deliver greater growth.

Finally the 'oceans as a driver of innovation' lens is perhaps the most glamorous version of the multiple Blue Economy interpretations. This lens promotes the seemingly limitless potential of the oceans by imagining them as sources of new discoveries and new wealth. Within this interpretation, tapping into this wealth, requires a nurturing technical and institutional environment, one which encourages risk taking and innovative thinking. 


\section{Conflicts and commonalities}

While the lack of a clearly articulated and agreed definition of the Blue Economy is seen by many as problematic, this analysis identifies much greater challenges lie in reconciling some of the inherent conflicts in the different interpretations of the concept, differences that are unlikely to be resolved through a definition. One of the most significant of these conflicts lies in the interpretations of which sectors can be legitimately included within the 'Blue Economy' umbrella. The inclusion of carbon intensive industries like oil and gas will, in particular, be a likely source of considerable conflict between the 'oceans as natural capital' and 'oceans as good business' lenses, as will the emerging, and increasingly controversial, deep sea mining sector (Filer and Gabriel, 2017). On one hand, the 'oceans as natural capital' lens would see inherent contradictions in the inclusion of carbon intensive industries in a model which seeks to address climate change, and would instead seek to promote a movement away from the extraction of non-renewable resources. Under this lens inclusion of these sectors as part of a Blue Economy would likely be seen as legitimizing destructive practices - or 'bluewashing'. On the other hand the 'oceans as good business' lens embraces these sectors, partially because this model of the Blue Economy relies heavily on valuation and accounting, including accounting for environmental externalities. Under this model it is therefore imperative that all sectors are incorporated, in order to accurately represent the economic value of ocean uses, and to accurately measure, account for and address the full suite of externalities.

Despite the areas of conflict there were also distinct commonalities across all the interpretations of the Blue Economy. These commonalities fall into three main areas and are explored in greater detail below. 


\section{Commodification}

Valuations studies were considered of primary importance across all the lenses of the Blue Economy, although the emphasis of these studies varied. All four lenses promoted the practice of quantifying the value of the natural capital provided by the oceans, and the 'oceans as good business' lens particularly focused on valuation of the ocean sectors and industries (the ocean economy). Despite criticisms of this approach as a form of neoliberalization of nature (Castree, 2010), proponents argue that quantification of use and non-use values provides a common language to assist in informing management actions, including spatial planning, and trade off decision making, as well as providing a means of more accurately accounting for the true cost of externalities (C. S. Colgan, 2016; Ebarvia, 2016; Mulazzani and Malorgio, 2017; Patil, et al., 2016). They argue it also provides an important tool to drive conservation through, for example, payment for ecosystem services such as carbon sequestration, or Blue Carbon (Lau, 2013;

Siikamäki, Sanchirico, Jardine, McLaughlin, \& Morris, 2013; Robin Warner, et al., 2016).

\section{Delimitation}

MSP was seen as a universal tool towards achieving a Blue Economy across all four lenses. MSP can be seen as the latest iteration of a long term historical trend towards greater demarcation of ownership and use which has emerged since the ratification of the UNCLOS (UNCLOS, 1982). MSP is seen to offer significant benefits through organizing and planning competing and sometimes conflicting activities, including protected areas, tourism, fishing and more heavy industries, such as shipping (Agardy, di Sciara, \& Christie, 2011; Crowder et al., 2006; Jay, Ellis, \& Kidd, 2012; Papageorgiou, 2016). 
Yet despite the promise of MSP in addressing many of the challenges facing oceans governance, the use of zoning to define permitted uses in a similar way to a land-based system of planning has been considered a challenge to the previous conceptualization of the oceans as a common property resource, with the potential for often unforeseen impacts (Kidd and Ellis, 2012). For example, it has been identified as a potential tool to facilitate 'ocean grabbing' if it results in the exclusion of traditional or cultural uses and negative impacts on livelihoods and wellbeing (Bennett, et al., 2015). In addition, the extent to which different objectives are emphasized within the MSP process can influence outcomes. For example, some European MSP processes have been criticised as favouring economic development interests at the expense of conservation objectives (Jones, Lieberknecht, \& Qiu, 2016). The lens through which the Blue Economy is interpreted may therefore have flow on implications for the way in which MSP is employed.

\section{Securitization}

Across all lens there is a recognition that the Blue Economy and maritime security are interdependent and interrelated concepts, reflecting the growing 'securitization' of ocean spaces (Bueger, 2015). Maritime security can be seen as both an enabler of the Blue Economy - for example, by protecting trade routes and providing important oceanographic and use data to industry - and as itself a sector of the Blue Economy (Voyer et al., 2018). Maritime security is seen as crucial to creating the secure and stable environment for the development of a Blue Economy.

As ocean spaces become increasingly crowded with often competing uses, across jurisdictional boundaries that are contested or poorly defined, the Blue Economy may also pose a serious threat by generating conflict and disputes. There is a need for further research into the complex interactions between the Blue Economy and the 
increased securitization of the oceans and its implications not just for ocean health but also global security (Bueger and Edmunds, 2017).

\section{Conclusion}

The Blue Economy is a notion that has emerged at a time of considerable change in the way in which oceans spaces are conceived and used. The Blue Economy attempts to bridge the gap between the economic opportunities provided by the oceans and the pressing need for improved environmental stewardship, protection and restoration. Understanding the different ways the Blue Economy is conceived and understood helps to identify areas of future potential conflict, as well as areas on which consensus-based, diplomatic approaches might be built. Future research should focus on the broad range of benefits the concept promises for community wellbeing and environmental health, however it should also draw attention to its potential pitfalls and challenges. Areas of consensus across the four interpretative lenses provide insights into what some of these challenges might be. What is the role of the Blue Economy in the 'neoliberalization' of the oceans, and is this a desirable path forward for oceans governance? How can the Blue Economy guard against the 'privatization' of common property ocean spaces? Finally, what role will the Blue Economy play in broader geopolitical disputes and efforts to maintain and protect ocean health and the safety of the communities that rely on it?

Commentary on the Blue Economy often calls for the adoption of an agreed definition. This analysis however points to some conflicts in interpretation that are likely to be irreconcilable. As such, any attempt to define the Blue Economy may result in particular lens being privileged, and undermine the ability of states or regions to develop a more contextualised Blue Economy which is sensitive to the aspirations and objectives of their communities. The Blue Economy is currently experiencing broad 
levels of support across a diverse suite of actors, and efforts to 'pin down' a definition for the Blue Economy are likely to undermine this support and bring to the surface these underlying tensions and inconsistencies in the way the term is currently being employed. An alternative approach may be to embrace the inherent ambiguities of the concept as opportunity for flexibility and adaptability. Under this scenario, it will be critical for future research to explore whether the four interpretations of the Blue Economy can co-exist in practice. This should focus on whether the conflicts between the different lenses of the Blue Economy can be accommodated or managed in a manner that recognises the differing priorities inherent in the different shades of blue.

\section{Acknowledgements}

This paper is built and expands upon earlier analysis completed for a report to the Sea Power Centre - Australia for the Pacific 2017 Conference. Thanks to anonymous reviewers of this and earlier drafts of this paper. Their comments and feedback significantly enhanced the quality of this manuscript. 


\section{References}

Agardy, T., di Sciara, G. N., \& Christie, P. (2011). Mind the gap: Addressing the shortcomings of marine protected areas through large scale marine spatial planning. Marine Policy, 35(2), pp. 226-232. doi:https://doi.org/10.1016/j.marpol.2010.10.006 Retrieved from http://www.sciencedirect.com/science/article/pii/S0308597X10001740

Anderson, Z. R., Kusters, K., McCarthy, J., \& Obidzinski, K. (2016). Green growth rhetoric versus reality: Insights from Indonesia. [Article]. Global Environmental Change, 38, pp. 30-40. doi:10.1016/j.gloenvcha.2016.02.008 Retrieved from http://ezproxy.uow.edu.au/login?url=http://search.ebscohost.com/login.aspx?dir ect $=$ true \&db=edselp\&AN=S095937801630019X\&site=eds-live

Anonymous. (2016). Abu Dhabi 2016 Blue Economy Declaration. Abu Dhabi Sustainability Week Summit, Abu Dhabi.

Arsel, M., \& Büscher, B. (2012). Nature ${ }^{\mathrm{TM}}$ Inc.: Changes and Continuities in Neoliberal Conservation and Market-based Environmental Policy. Development and Change, 43(1), pp. 53-78. doi:10.1111/j.1467-7660.2012.01752.x Retrieved from http://dx.doi.org/10.1111/j.1467-7660.2012.01752.x

Beaudoin, Y., \& Pendleton, L. (2012). Why Value the Oceans? A Discussion Paper. T. E. o. E. a. Biodiversity. http://www.teebweb.org/areas-of-work/biomestudies/teeb-for-oceans-and-coasts/

Bennett, N. J., Govan, H., \& Satterfield, T. (2015). Ocean grabbing. Marine Policy, 57, pp. 61-68. doi:http://dx.doi.org/10.1016/j.marpol.2015.03.026 Retrieved from http://www.sciencedirect.com/science/article/pii/S0308597X15000755

Biermann, F., Kanie, N., \& Kim, R. E. (2017). Global governance by goal-setting: the novel approach of the UN Sustainable Development Goals. [Review Article]. Current Opinion in Environmental Sustainability, 26-27, pp. 26-31. doi:10.1016/j.cosust.2017.01.010 Retrieved from http://ezproxy.uow.edu.au/login?url=http://search.ebscohost.com/login.aspx?dir ect $=$ true \&db=edselp\&AN=S1877343517300209\&site=eds-live

Blue Ribbon Panel to the Global Partnerships for Oceans. (2013). Indispensible Ocean: Alighning ocean health and human wellbeing www.globalpartnershipforoceans.org/indispensable-ocean

Bowen, A., \& Fankhauser, S. (2011). The green growth narrative: Paradigm shift or just spin? Global Environmental Change, 21(4), pp. 1157-1159. doi:http://dx.doi.org/10.1016/j.gloenvcha.2011.07.007 Retrieved from http://www.sciencedirect.com/science/article/pii/S0959378011001129

Brockington, D., \& Ponte, S. (2015). The Green Economy in the global South: experiences, redistributions and resistance. [Article]. Third World Quarterly, 36(12), pp. 2197-2206. doi:10.1080/01436597.2015.1086639 Retrieved from http://ezproxy.uow.edu.au/login?url=http://search.ebscohost.com/login.aspx?dir ect $=$ true $\& \mathrm{db}=\mathrm{bth} \& \mathrm{AN}=111657983 \&$ site $=$ eds-live

Brundtland, G. H. (1987). Our common future Melbourne: Oxford University Press.

Bueger, C. (2015). What is maritime security? Marine Policy, 53, pp. 159-164. doi:https://doi.org/10.1016/j.marpol.2014.12.005 Retrieved from http://www.sciencedirect.com/science/article/pii/S0308597X14003327

Bueger, C., \& Edmunds, T. (2017). Beyond seablindness: a new agenda for maritime security studies. International Affairs, pp. iix174-iix174. doi:10.1093/ia/iix 174 Retrieved from http://dx.doi.org/10.1093/ia/iix174

Bush, S. R., M. Bottema, Midavaine, J. J., \& Carter, E. (2017). Sustainability entrepreneurship in marine protected areas In K. Nicolopoulou, M. Karatas- 
Ozkan, F. Janssen \& J. Jermier (Eds.), Sustainable Entrepreneurship and Social Innovation (pp. 124-140). New York: Routledge.

Castree, N. (2010). Neoliberalism and the Biophysical Environment 1: What

'Neoliberalism' is, and What Difference Nature Makes to it. Geography

Compass, 4(12), p 1725. Retrieved from

http://ezproxy.uow.edu.au/login?url=http://search.ebscohost.com/login.aspx?dir ect $=$ true $\& \mathrm{db}=$ edo \&AN=ejs22630095\&site $=$ eds-live

Chaigneau, T., \& Brown, K. (2016). Challenging the win-win discourse on conservation and development: Analyzing support for marine protected areas. [Article]. Ecology and Society, 21(1)doi:10.5751/ES-08204-210136 Retrieved from http://ezproxy.uow.edu.au/login?url=http://search.ebscohost.com/login.aspx?dir ect=true \&db=edselc\&AN=edselc.2-52.0-84962632057\&site=eds-live

Choi, Y. R. (2017). The Blue Economy as governmentality and the making of new spatial rationalities. Dialogues in Human Geography, 7(1), pp. 37-41. doi:10.1177/2043820617691649 Retrieved from http://dx.doi.org/10.1177/2043820617691649

Colgan, C. (2003). Measurement of the ocean and coastal economy: theory and methods. USA

Colgan, C. S. (2016). Measurement of the Ocean Economy From National Income Accounts to the Sustainable Blue Economy. Journal of Ocean and Coastal Economics, 2(12)doi:DOI: http://dx.doi.org/10.15351/2373-8456.1061

Corazon Ebarvia, M., \& Habito, C. (2014). Nurturing Sustainable and Inclusive Coastal and Ocean-based Blue Economy. Tropical Coasts, 4-23.

Corson, C., MacDonald, K. I., \& Neimark, B. (2013). Grabbing "green": markets, environmental governance and the materialization of natural capital. Human Geography, 6(1), pp. 1-15.

Crowder, L. B., Osherenko, G., Young, O. R., Airamé, S., Norse, E. A., Baron, N., . . . Wilson, J. A. (2006). Resolving Mismatches in U.S. Ocean Governance. Science, 313(5787), pp. 617-618. doi:10.1126/science.1129706 Retrieved from http://science.sciencemag.org/content/sci/313/5787/617.full.pdf

CSIRO. (2015). Innovation for the Blue Economy: Workshop Summary. Notes from a workshop co-hosted by CSIRO and the Department of Foreign Affairs and Trade's innovationXchange. Canberra, ACT

Dreher, T., \& Voyer, M. (2015). Climate Refugees or Migrants? Contesting Media Frames on Climate Justice in the Pacific. [Article]. Environmental Communication, 9(1), pp. 58-76. doi:10.1080/17524032.2014.932818 Retrieved from

http://ezproxy.uow.edu.au/login?url=http://search.ebscohost.com/login.aspx?dir ect $=$ true \&db=eih\&AN=101384260\&site=eds-live

East Asian Seas Congress. (2012). Building a Blue Economy: Strategy, Opportunities and Partnerships in the Seas of East Asia. Proceedings of the Fourth Ministerial Forum on the Sustainable Development of the Seas of East Asia, Changwon City, Republic of Korea.

Ebarvia, M. C. M. (2016). Economic Assessment of Oceans for Sustainable Blue Economy Development. Journal of Ocean and Coastal Economics:, 2doi:DOI: http://dx.doi.org/10.15351/2373-8456.1051

ECORYS Nederland BV. (2012). Blue Growth: Scenarios and drivers for Sustainable Growth from the Oceans, Seas and Coasts. Rotterdame/Brussels

Eikeset, A. M., Mazzarella, A. B., Davíðsdóttir, B., Klinger, D. H., Levin, S. A., Rovenskaya, E., \& Stenseth, N. C. (2018). What is blue growth? The semantics 
of "Sustainable Development" of marine environments. Marine Policy, 87, pp. 177-179. doi:https://doi.org/10.1016/j.marpol.2017.10.019 Retrieved from https://www.sciencedirect.com/science/article/pii/S0308597X17306905

EIU, EDF, Gordon and Betty Moore Foundation, David and Lucile Packard Foundation, CEA, UCSB, \& UW. (2017). Ocean Prosperity Roadmap: Fisheries and Beyond. www.oceanprosperityroadmap.org

Engler, C. (2015). Beyond rhetoric: navigating the conceptual tangle towards effective implementation of the ecosystem approach to oceans management. [Article]. Environmental Reviews, 23(3), pp. 288-320. doi:10.1139/er-2014-0049 Retrieved from http://ezproxy.uow.edu.au/login?url=http://search.ebscohost.com/login.aspx?dir ect=true \&db=eih\&AN=109171951\&site=eds-live

ERISS Corporation, \& The Maritime Alliance. (2017). The Ocean Enterprise: A study of US business activity in ocean measurement, observation and forecasting. I. O. O. S. (IOOS) \& N. O. a. A. A. (NOAA). https://ioos.noaa.gov/wpcontent/uploads/2017/04/oceanenterprise_feb2017_secure.pdf

European Commission. (2012a). Blue Growth: Opportunities for marine and maritime sustainable growth. Communication from the Commission to the European Parliament, the Council, the European Economic and Social Committee and the Committee of the Regions. L. P. O. o. t. E. Union.

European Commission. (2012b). Progress of the EU's Integrated Maritime Policy, Report from the Commission to the European Parliament, the Council, the European Economic and Social Committee and the Committee of the Regions.

European Commission. (2014). Innovation in the Blue Economy: realising the potential of our seas and oceans for jobs and growth. Communication from the Commission to the European Parliament, the Council, the European Economic and Social Committee and the Committee of the Regions. Brussels

FAO. (2014a). Asia and the Pacific's Blue Growth Initiative. In F. a. A. O. o. t. U. Nations (Ed.). http://www.fao.org/3/a-ml968e/ml968e06.pdf: FAO.

FAO. (2014b). Global Blue Growth Initiative and Small Island Developing States (SIDS). http://www.fao.org/publications/card/en/c/c8aeb23f-f794-410e-804f2aa82140d34a/

FAO. (2016) Blue Growth. Paper presented at the FAO Regional Conference for Asia and the Pacific, Malaysia.

Filer, C., \& Gabriel, J. (2017). How could Nautilus Minerals get a social licence to operate the world's first deep sea mine? Marine Policydoi:http://dx.doi.org/10.1016/j.marpol.2016.12.001 Retrieved from http://www.sciencedirect.com/science/article/pii/S0308597X16306625

Global Oceans Action Summit. (2014). Global Oceans Action Summit for Food Security and Blue Growth CHAIR's SUMMARY. Global Oceans Action Summit, The Hague, Netherlands.

Gordon, D., Murray, B. C., Pendleton, L., \& Victor, B. (2011). Financing Options for Blue Carbon Opportunities and Lessons from the REDD+Experience. D. University.

Government of India, \& RIS. (2015). Goa Declaration. IORA Blue Economy Dialogue on Prospects of Blue Economy in the Indian Ocean, Goa, India.

Greenhill, L., Hughes, A., Day, J. G., \& Stanley, M. S. (2015). Developing Knowledge to Transition to a Blue Economy: A Strategic Approach. Island Studies: Indian Ocean(3), pp. 6-10. 
Gulf Coast Community Foundation. (2015). Developing the Blue economy of Florida's Gulf Coast: A srategic roadmap for innovation and growth in the marine sciences cluster. Florida: Gulf Coast Community Foundation.

Holthus, P. (2017, 15 June). The Business of Ocean Sustainable Development. Retrieved from http://sdg.iisd.org/commentary/guest-articles/the-business-ofocean-sustainable-development/

IOC/UNESCO, IMO, FAO, \& UNDP. (2011). A Blueprint for Ocean and Coastal Sustainability. Paris:

Jay, S., Ellis, G., \& Kidd, S. (2012). Marine Spatial Planning: A New Frontier? Journal of Environmental Policy \& Planning, 14(1), pp. 1-5. doi:10.1080/1523908X.2012.664327 Retrieved from https://doi.org/10.1080/1523908X.2012.664327

Johansen, B. (2015). Eco-Hustle! : Global Warming, Greenwashing, And Sustainability Santa Barbara, California: Praeger.

Jones, P. J. S., Lieberknecht, L. M., \& Qiu, W. (2016). Marine spatial planning in reality: Introduction to case studies and discussion of findings. Marine Policy, 71, pp. 256-264. doi:https://doi.org/10.1016/j.marpol.2016.04.026 Retrieved from http://www.sciencedirect.com/science/article/pii/S0308597X16302147

Karim, M. A. (2015). China's Proposed Maritime Silk Road: Challenges and Opportunities with Special Reference to the Bay of Bengal Region. [Article]. Pacific Focus, 30(3), pp. 297-319. doi:10.1111/pafo.12059 Retrieved from http://ezproxy.uow.edu.au/login?url=http://search.ebscohost.com/login.aspx?dir ect $=$ true \&db=poh\&AN=111967772\&site $=$ eds-live

Keen, M. R., Schwarz, A.-M., \& Wini-Simeon, L. (2017). Towards defining the Blue Economy: Practical lessons from pacific ocean governance. Marine Policydoi:http://dx.doi.org/10.1016/j.marpol.2017.03.002 Retrieved from http://www.sciencedirect.com/science/article/pii/S0308597X16308235

Khurana, G. S. (2016). China as an Indian Ocean power: trends and implications. Maritime affairs (New Delhi, India), 12(1), pp. 13-24. doi:10.1080/09733159.2016.1175127

Kidd, S., \& Ellis, G. (2012). From the Land to Sea and Back Again? Using Terrestrial Planning to Understand the Process of Marine Spatial Planning. Journal of Environmental Policy \& Planning, 14(1), pp. 49-66. doi:10.1080/1523908X.2012.662382 Retrieved from https://doi.org/10.1080/1523908X.2012.662382

Kildow, J. T., \& McIlgorm, A. (2010). The importance of estimating the contribution of the oceans to national economies. Marine Policy, 34(3), pp. 367-374. doi:http://dx.doi.org/10.1016/j.marpol.2009.08.006 Retrieved from http://www.sciencedirect.com/science/article/pii/S0308597X09001225

Lau, W. W. Y. (2013). Beyond carbon: Conceptualizing payments for ecosystem services in blue forests on carbon and other marine and coastal ecosystem services. Ocean \& Coastal Management, 83, pp. 5-14. doi:http://dx.doi.org/10.1016/j.ocecoaman.2012.03.011 Retrieved from http://www.sciencedirect.com/science/article/pii/S0964569112000671

Lightfoot, S., \& Burchell, J. (2004). Green hope or greenwash? The actions of the European Union at the World Summit on sustainable development. [Article]. Global Environmental Change, 14, pp. 337-344. doi:10.1016/j.gloenvcha.2004.07.002 Retrieved from http://ezproxy.uow.edu.au/login?url=http://search.ebscohost.com/login.aspx?dir

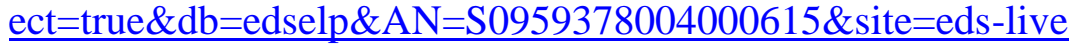


Llewellyn, L. E., English, S., \& Barnwell, S. (2016). A roadmap to a sustainable Indian Ocean blue economy. [Article]. Journal of the Indian Ocean Region, 12(1), pp. 52-66. doi:10.1080/19480881.2016.1138713 Retrieved from

http://ezproxy.uow.edu.au/login?url=http://search.ebscohost.com/login.aspx?dir ect $=$ true $\& d b=a 9 h \& A N=113220227 \&$ site $=e d s-l i v e$

Lu, W.-H., Liu, J., Xiang, X.-Q., Song, W.-L., \& McIlgorm, A. (2015). A comparison of marine spatial planning approaches in China: Marine functional zoning and the marine ecological red line. Marine Policy, 62, pp. 94-101. doi:https://doi.org/10.1016/j.marpol.2015.09.004 Retrieved from http://www.sciencedirect.com/science/article/pii/S0308597X15002559

Marquis, C. Scrutiny, Norms, and Selective Disclosure: A Global Study of Greenwashing. Organization science (Providence, R.I.), 27(2), pp. 483-504.

McIlgorm, A. (2005). Economic Value of the Marine Sector Across the APEC Marine Economies. Draft report to the APEC Marine Resource Conservation Working Group Project (05/2004), . The Centre for Marine Policy: U. o. Wollongong.

McIlgorm, A. (2016). Ocean Economy Valuation Studies in the Asia-Pacific Region: Lessons for the Future International Use of National Accounts in the Blue Economy. Journal of Ocean and Coastal Economics, 2doi:DOI: http://dx.doi.org/10.15351/2373-8456.1046

Mengjie. (2017). Vision for Maritime Cooperation under the Belt and Road Initiative. Xinhuanet. Retrieved 19/07/17.

Michel, J. A. (2016). Rethinking the Oceans: Towards the Blue Economy United States: Paragon House.

Mohanty, S. K., Dash, P., Gupta, A., \& Gaur, P. (2015). Prospects of Blue Economy in the Indian Ocean. New Delhi, india

Mulazzani, L., \& Malorgio, G. (2017). Blue growth and ecosystem services. Marine Policy, 85, pp. 17-24. doi:https://doi.org/10.1016/j.marpol.2017.08.006 Retrieved from https://www.sciencedirect.com/science/article/pii/S0308597X17301021

National Marine Science Committee. (2015). National Marine Science Plan 2015-2025: Driving the development of Australia's blue economy. Townsville: http://frdc.com.au/environment/NMSC-WHITE/Documents/NMSP\%2020152025\%20report.pdf

National Maritime Foundation. (2017). The Blue Economy: Concept, Constituents and Development. Anual Maritime Power Conference, New Delhi, India.

New Economics Foundation. (2015). New Blue Deal: Good jobs for coastal communities through healthy seas. UK

OECD. (2016). The Ocean Economy in 2030, . O. Publishing. http://www.oecdilibrary.org/economics/the-ocean-economy-in-2030_9789264251724-en

Papageorgiou, M. (2016). Coastal and marine tourism: A challenging factor in Marine Spatial Planning. Ocean \& Coastal Management, 129, pp. 44-48. doi:http://dx.doi.org/10.1016/j.ocecoaman.2016.05.006 Retrieved from http://www.sciencedirect.com/science/article/pii/S0964569116300965

Patil, P. G., Virdin, J., Diez, S. M., Roberts, J., \& Singh, A. (2016). Toward A Blue Economy: A Promise for Sustainable Growth in the Caribbean; An Overview. . Washington D.C.

Pauli, G. A. (2010). The Blue Economy: 10 Years, 100 Innovations, 100 Million Jobs Taos, New Mexico: Paradigm Publications.

Phelps, J., Friess, D. A., \& Webb, E. L. (2012). Special Issue Article: REDD+and conservation: Win-win REDD+ approaches belie carbon-biodiversity trade- 
offs. [Article]. Biological Conservation, 154, pp. 53-60.

doi:10.1016/j.biocon.2011.12.031 Retrieved from

http://ezproxy.uow.edu.au/login?url=http://search.ebscohost.com/login.aspx?dir ect $=$ true \&db=edselp\&AN=S0006320711004940\&site=eds-live

Purvis, M.-T. (2015). Seychelles Blue Economy Strategy. Island Studies: Indian Ocean (3), pp. 14-19.

Roberts, J., \& Ali, A. (2016). The Blue Economy and Small States. . London

Rustomjee, C. (2016). Financing the Blue Economy in Small States. Policy Brief, 78. Retrieved.

Siikamäki, J., Sanchirico, J. N., Jardine, S., McLaughlin, D., \& Morris, D. (2013). Blue Carbon: Coastal Ecosystems, Their Carbon Storage, and Potential for Reducing Emissions. Environment: Science and Policy for Sustainable Development, 55(6), pp. 14-29. doi:10.1080/00139157.2013.843981 Retrieved from http://dx.doi.org/10.1080/00139157.2013.843981

Silver, J. J., Gray, N. J., Campbell, L. M., Fairbanks, L. W., \& Gruby, R. L. (2015). Blue Economy and Competing Discourses in International Oceans Governance. The Journal of Environment \& Development, 24(2), pp. 135-160. doi:10.1177/1070496515580797 Retrieved from http://jed.sagepub.com/content/24/2/135.abstract

Smith-Godfrey, S. (2016). Defining the Blue Economy. Maritime Affairs: Journal of the National Maritime Foundation of India, 12(1), pp. 58-64. doi:10.1080/09733159.2016.1175131 Retrieved from http://dx.doi.org/10.1080/09733159.2016.1175131

SPREP. (2011). The "Blue Economy”: A Pacific Small Island Developing States Perspective. Rio+20 Pacific Preparatory Meeting,, Apia, Samoa.

The Economist. (2015). The blue economy: Growth, opportunity and a sustainable ocean economy. An Economist Intelligence Unit briefing paper for the World Ocean Summit 2015. London:

http://www.eiuperspectives.economist.com/sites/default/files/Blue\%20Economy briefing\%20paper_WOS2015.pdf

United Nations Convention on the Law of the Sea, 1833 (1982).

UNCTAD. (2014). The oceans economy: opportunities and challenges for Small Island States. Geneva

UNEP. (2011). Towards a Green Economy: Pathways to Sustainable Development and Poverty Eradication. www.unep.org/greeneconomy

UNEP, FAO, IMO, UNDP, IUCN, Center, W. F., \& GRIDArendal. (2012). Green Economy in a Blue World. Nairobi, Kenya: www.unep.org/greeneconomy and www.unep.org/regionalseas

United Nations. (2014) Blue Economy Concept Paper. Paper presented at the Blue Economy Summit., Abu Dhabi, United Arab Emirates. https://sustainabledevelopment.un.org/content/documents/2978BEconcept.pdf

Voyer, M., Schofield, C., Azmi, K., Warner, R., McIlgorm, A., \& Quirk, G. (2018). Maritime security and the Blue Economy: intersections and interdependencies in the Indian Ocean. Journal of the Indian Ocean Region, pp. 1-21. doi:10.1080/19480881.2018.1418155 Retrieved from https://doi.org/10.1080/19480881.2018.1418155

Walsh, K. (2017). Sea control 142 - the blue economy and ocean clusters In K. Walsh (Ed.), Asia Pacific Sea Control. http://cimsec.org/sea-control-142-blueeconomy-ocean-clusters-kate-walsh/33806: Centre for International Maritime Security. 
Warner, R. (2009). Protecting the oceans beyond national jurisdiction : strengthening the international law framework / Leiden ; Boston: Martinus Nijhoff Publishers.

Warner, R., Kaidonis, M., Dun, O., Rogers, K., Shi, Y., Nguyen, T., \& Woodroffe, C. (2016). Opportunities and challenges for mangrove carbon sequestration in the Mekong River Delta in Vietnam. [Article]. Sustainability Science, 11(4), pp. 661-677. doi:10.1007/s11625-016-0359-3 Retrieved from http://ezproxy.uow.edu.au/login?url=http://search.ebscohost.com/login.aspx?dir ect=true \&db=eih\&AN=116170495\&site=eds-live

Whisnant, R., \& Reyes, A. (2015). Blue Economy for Business in East Asia: Towards an Integrated Understanding of Blue Economy. Quezon City, Philippines.

Winder, G. M., \& Le Heron, R. (2017). Assembling a Blue Economy moment? Geographic engagement with globalizing biological-economic relations in multiuse marine environments. Dialogues in Human Geography, 7(1), pp. 3-26. doi:10.1177/2043820617691643 Retrieved from http://dx.doi.org/10.1177/2043820617691643

World Bank. (2017). Pacific Possible: Long-term Economic Opportunities and Challenges for Pacific Island Countries. . Washington, DC

World Bank and United Nations Department of Economic and Social Affairs. (2017). The Potential of the Blue Economy: Increasing Long-term Benefits of the Sustainable Use of Marine Resources for Small Island Developing States and Coastal Least Developed Countries. . Washington DC.

WWF Baltic Ecoregion Programme. (2015). Principles for a Sustainable Blue Economy. http://wwf.panda.org/wwf_news/?247477/Principles-for-aSustainable-Blue-Economy\# 
Table 1 - Sectors that contribute to the ocean economy (adapted from The Economist, 2015)

\begin{tabular}{|c|c|c|c|}
\hline $\begin{array}{l}\text { Extraction of non-living } \\
\text { resources, or resource } \\
\text { generation }\end{array}$ & $\begin{array}{l}\text { Harvesting of living } \\
\text { resources }\end{array}$ & $\begin{array}{l}\text { Commerce and trade in } \\
\text { and around the ocean }\end{array}$ & $\begin{array}{l}\text { Ecosystem protection and } \\
\text { management }\end{array}$ \\
\hline $\begin{array}{l}\text { Seabed/ Deep seabed } \\
\text { mining }\end{array}$ & Fisheries & $\begin{array}{l}\text { Shipping (marine } \\
\text { transportation) }\end{array}$ & Blue Carbon \\
\hline Oil and gas & Aquaculture & Shipbuilding and repair & $\begin{array}{l}\text { Surveillance and maritime } \\
\text { security }\end{array}$ \\
\hline Water (desalinization) & Marine bio-technology & $\begin{array}{l}\text { Marine construction (e.g. } \\
\text { jetties etc.) }\end{array}$ & $\begin{array}{l}\text { Habitat protection/ } \\
\text { restoration }\end{array}$ \\
\hline Dredging & \multicolumn{2}{|c|}{ Recreational fishing and boating } & Hazard protection \\
\hline $\begin{array}{l}\text { Energy/renewables } \\
\text { (tidal/wave energy; } \\
\text { coastal/offshore wind) }\end{array}$ & Seafood processing & $\begin{array}{l}\text { Port infrastructure and } \\
\text { services }\end{array}$ & $\begin{array}{l}\text { Ecological/ ecosystem } \\
\text { research }\end{array}$ \\
\hline & & $\begin{array}{l}\text { Marine services (e.g. } \\
\text { mapping, monitoring, } \\
\text { consulting, maritime } \\
\text { insurance, etc.) }\end{array}$ & $\begin{array}{l}\text { Waste treatment and } \\
\text { disposal }\end{array}$ \\
\hline & & \multicolumn{2}{|l|}{ Marine education and R\&D } \\
\hline & & Coastal Development & \\
\hline & & $\begin{array}{l}\text { Marine and coastal } \\
\text { tourism }\end{array}$ & \\
\hline & & Defense & \\
\hline
\end{tabular}


Table 2. Selected Blue Economy documents

\begin{tabular}{|c|c|c|c|c|}
\hline Year & Organisation & Region & Title & Document type \\
\hline 2011 & $\begin{array}{l}\text { Government or } \\
\text { intergovernmental group }\end{array}$ & Global/undefined & $\begin{array}{l}\text { A Blueprint For Ocean And Coastal Sustainability (IOC/UNESCO, IMO, FAO, \& UNDP, } \\
\text { 2011) }\end{array}$ & Report \\
\hline 2012 & $\begin{array}{l}\text { Government or } \\
\text { intergovernmental group }\end{array}$ & Europe & $\begin{array}{l}\text { Blue Growth: Scenarios and drivers for Sustainable Growth from the Oceans, Seas and } \\
\text { Coasts. Report for the European Commission (ECORYS Nederland BV, 2012) }\end{array}$ & $\begin{array}{l}\text { Consultancy } \\
\text { report }\end{array}$ \\
\hline 2012 & $\begin{array}{l}\text { Government or } \\
\text { intergovernmental group }\end{array}$ & Europe & $\begin{array}{l}\text { Blue Growth: Opportunities for marine and maritime sustainable growth (European } \\
\text { Commission, 2012a). }\end{array}$ & Briefing \\
\hline 2012 & $\begin{array}{l}\text { Government or } \\
\text { intergovernmental group }\end{array}$ & Europe & Progress of the EU's Integrated Maritime Policy (European Commission, 2012b) & Briefing \\
\hline 2012 & Development organisation & Global/undefined & Green Economy in a Blue World (UNEP et al., 2012) & Report \\
\hline 2012 & Development organisation & Pacific & $\begin{array}{l}\text { The "Blue Economy": A Pacific Small Island Developing States Perspective (SPREP, } \\
\text { 2011) }\end{array}$ & Report \\
\hline 2012 & $\begin{array}{l}\text { Government or } \\
\text { intergovernmental group }\end{array}$ & East Asia & $\begin{array}{l}\text { Nurturing Sustainable and Inclusive Coastal and Ocean-based Blue Economy. Tropical } \\
\text { Coasts (Corazon Ebarvia and Habito, 2014) }\end{array}$ & $\begin{array}{l}\text { Conference } \\
\text { proceedings }\end{array}$ \\
\hline 2013 & Academic or think tank & Global/undefined & $\begin{array}{l}\text { Indispensible Ocean: Aligning ocean health and human wellbeing (Blue Ribbon Panel } \\
\text { to the Global Partnerships for Oceans, 2013) }\end{array}$ & Report \\
\hline 2014 & $\begin{array}{l}\text { Government or } \\
\text { intergovernmental group }\end{array}$ & Global/undefined & Blue Economy Concept Paper. Blue Economy Summit(United Nations, 2014). & Report \\
\hline 2014 & $\begin{array}{l}\text { Government or } \\
\text { intergovernmental group }\end{array}$ & Europe & $\begin{array}{l}\text { Innovation in the Blue Economy: realizing the potential of our seas and oceans for jobs } \\
\text { and growth (European Commission, 2014) }\end{array}$ & Briefing \\
\hline 2014 & Development organisation & East Asia & Asia and the Pacific's Blue Growth Initiative (FAO, 2014a) & Briefing \\
\hline 2014 & Development organisation & Global/undefined & $\begin{array}{l}\text { Global Oceans Action Summit for Food Security and Blue Growth Chair's } \\
\text { Summary(Global Oceans Action Summit, 2014) }\end{array}$ & $\begin{array}{l}\text { Conference } \\
\text { proceedings }\end{array}$ \\
\hline 2014 & Development organisation & Pacific & Global Blue Growth Initiative and Small Island Developing States (SIDS)(FAO, 2014b) & Report \\
\hline 2014 & Development organisation & Global/undefined & $\begin{array}{l}\text { The oceans economy: opportunities and challenges for Small Island States (UNCTAD, } \\
\text { 2014) }\end{array}$ & Report \\
\hline 2015 & Industry group & Global/undefined & $\begin{array}{l}\text { The Blue Economy: Growth, opportunity and a sustainable ocean economy (The } \\
\text { Economist, 2015) }\end{array}$ & Briefing \\
\hline
\end{tabular}




\begin{tabular}{|c|c|c|c|c|}
\hline 2015 & $\begin{array}{l}\text { Government or } \\
\text { intergovernmental group }\end{array}$ & Indian Ocean & Prospects of Blue Economy in the Indian Ocean(Mohanty, et al., 2015) & Report \\
\hline 2015 & NGO & Americas & $\begin{array}{l}\text { Developing the Blue Economy of Florida's Gulf Coast: A strategic roadmap for } \\
\text { innovation and growth in the marine sciences cluster. (Gulf Coast Community } \\
\text { Foundation, 2015) }\end{array}$ & Report \\
\hline 2015 & $\begin{array}{l}\text { Government or } \\
\text { intergovernmental group }\end{array}$ & Indian Ocean & Goa Declaration (Government of India and RIS, 2015) & $\begin{array}{l}\text { Conference } \\
\text { proceedings }\end{array}$ \\
\hline 2015 & $\begin{array}{l}\text { Government or } \\
\text { intergovernmental group }\end{array}$ & Australia & Innovation for the Blue Economy: Workshop Summary (CSIRO, 2015) & Report \\
\hline 2015 & NGO & United Kingdom & New Blue Deal (New Economics Foundation, 2015) & Report \\
\hline 2015 & Academic or think tank & Australia & $\begin{array}{l}\text { National Marine Science Plan 2015-2025: Driving the development of Australia's Blue } \\
\text { Economy(National Marine Science Committee, 2015) }\end{array}$ & Report \\
\hline 2015 & $\begin{array}{l}\text { Government or } \\
\text { intergovernmental group }\end{array}$ & East Asia & $\begin{array}{l}\text { Blue Economy for Business in East Asia: Towards an Integrated Understanding of Blue } \\
\text { Economy (Whisnant and Reyes, 2015) }\end{array}$ & Report \\
\hline 2015 & NGO & Global/undefined & Principles for a Sustainable Blue Economy(WWF Baltic Ecoregion Programme, 2015) & Report \\
\hline 2016 & Development organisation & Americas & $\begin{array}{l}\text { Toward A Blue Economy: A Promise for Sustainable Growth in the Caribbean; An } \\
\text { Overview(Patil, et al., 2016) }\end{array}$ & Report \\
\hline 2016 & $\begin{array}{l}\text { Government or } \\
\text { intergovernmental group }\end{array}$ & Global/undefined & Abu Dhabi 2016 Blue Economy Declaration (Anonymous, 2016) & $\begin{array}{l}\text { Conference } \\
\text { proceedings }\end{array}$ \\
\hline 2016 & $\begin{array}{l}\text { Government or } \\
\text { intergovernmental group }\end{array}$ & Global/undefined & The Blue Economy and Small States(Roberts and Ali, 2016) & Report \\
\hline 2016 & Development organisation & East Asia & Blue Growth (FAO, 2016) & $\begin{array}{l}\text { Conference } \\
\text { proceedings }\end{array}$ \\
\hline 2016 & Academic or think tank & Indian Ocean & $\begin{array}{l}\text { A roadmap to a sustainable Indian Ocean Blue Economy (Llewellyn, English, \& } \\
\text { Barnwell, 2016) }\end{array}$ & Journal article \\
\hline 2016 & $\begin{array}{l}\text { Government or } \\
\text { intergovernmental group }\end{array}$ & Global/undefined & The Ocean Economy in 2030 (OECD, 2016) & Report \\
\hline 2016 & $\begin{array}{l}\text { Government or } \\
\text { intergovernmental group }\end{array}$ & Pacific & Financing the Blue Economy in Small States (Rustomjee, 2016) & Briefing \\
\hline 2017 & Development organisation & Pacific & $\begin{array}{l}\text { Pacific Possible: Long-term Economic Opportunities and Challenges for Pacific Island } \\
\text { Countries (World Bank, 2017) }\end{array}$ & Report \\
\hline 2017 & $\begin{array}{l}\text { Government or } \\
\text { intergovernmental group }\end{array}$ & Indian Ocean & $\begin{array}{l}\text { The Blue Economy: Concept, Constituents and Development (National Maritime } \\
\text { Foundation, 2017) }\end{array}$ & $\begin{array}{l}\text { Conference } \\
\text { proceedings }\end{array}$ \\
\hline
\end{tabular}




\begin{tabular}{|l|l|l|l|}
2017 & Academic or think tank & Americas & Ocean Prosperity Roadmap: Fisheries and Beyond (EIU et al., 2017) \\
\hline 2017 & $\begin{array}{l}\text { Government or } \\
\text { intergovernmental group }\end{array}$ & Americas & $\begin{array}{l}\text { The Ocean Enterprise: A study of US business activity in ocean measurement, } \\
\text { observation and forecasting(ERISS Corporation and The Maritime Alliance, 2017) }\end{array}$ \\
\hline 2017 & $\begin{array}{l}\text { Government or } \\
\text { intergovernmental group }\end{array}$ & Global/undefined & $\begin{array}{l}\text { The Potential of the Blue Economy: Increasing Long-Term Benefits of the Sustainable } \\
\text { Use of Marine Resources for Small Island Developing States and Coastal Least } \\
\text { Developed Countries (World Bank and United Nations Department of Economic and } \\
\text { Social Affairs, 2017) }\end{array}$ \\
\hline 2017 & $\begin{array}{l}\text { Government or } \\
\text { intergovernmental group }\end{array}$ & East Asia & Vision for Maritime Cooperation under the Belt and Road Initiative(Mengjie, 2017) \\
\hline
\end{tabular}


Table 3. Key themes and sub-themes within Blue Economy grey literature, noting number and percentage of documents in which the concepts were referenced

\begin{tabular}{|c|c|c|c|c|c|c|c|c|c|}
\hline \multicolumn{2}{|c|}{ Economic themes } & \multicolumn{2}{|c|}{ Environmental themes } & \multicolumn{2}{|c|}{ Social themes } & \multicolumn{2}{|c|}{$\begin{array}{l}\text { Innovation and } \\
\text { technical capacity }\end{array}$} & \multicolumn{2}{|c|}{$\begin{array}{c}\text { Governance tools or } \\
\text { approaches }\end{array}$} \\
\hline \begin{tabular}{|l} 
Blue \\
(Economic) \\
growth
\end{tabular} & $\begin{array}{c}29 \\
(78 \%)\end{array}$ & $\begin{array}{l}\text { Sustainability/ } \\
\text { balance }\end{array}$ & $\begin{array}{c}21 \\
(57 \%)\end{array}$ & $\begin{array}{l}\text { Capacity } \\
\text { building }\end{array}$ & $\begin{array}{c}21 \\
(57 \%)\end{array}$ & $\begin{array}{l}\text { Innovation } \\
\text { (technical) }\end{array}$ & $\begin{array}{c}29 \\
(78 \%)\end{array}$ & $\begin{array}{l}\text { Co-ordination/ } \\
\text { integration }\end{array}$ & $\begin{array}{c}27 \\
(73 \%)\end{array}$ \\
\hline $\begin{array}{l}\text { Growth } \\
\text { strategy (sector } \\
\text { based) }\end{array}$ & $\begin{array}{c}26 \\
(70 \%)\end{array}$ & $\begin{array}{l}\text { Impact } \\
\text { abatement or } \\
\text { mitigation }\end{array}$ & $\begin{array}{c}20 \\
(54 \%)\end{array}$ & Food security & $\begin{array}{c}19 \\
(51 \%)\end{array}$ & $\begin{array}{l}\text { Security and/or } \\
\text { surveillance }\end{array}$ & $\begin{array}{c}22 \\
(59 \%)\end{array}$ & $\begin{array}{l}\text { Effective } \\
\text { governance or } \\
\text { regulatory } \\
\text { frameworks } \\
\end{array}$ & $\begin{array}{c}18 \\
(49 \%)\end{array}$ \\
\hline Employment & $\begin{array}{c}15 \\
(41 \%)\end{array}$ & $\begin{array}{l}\text { De- } \\
\text { carbonization/ } \\
\text { climate change } \\
\text { mitigation }\end{array}$ & $\begin{array}{c}18 \\
(49 \%)\end{array}$ & $\begin{array}{l}\text { Poverty } \\
\text { alleviation }\end{array}$ & $\begin{array}{c}15 \\
(41 \%)\end{array}$ & Investment & $\begin{array}{c}20 \\
(54 \%)\end{array}$ & $\begin{array}{l}\text { Marine Spatial } \\
\text { Planning (MSP) }\end{array}$ & $\begin{array}{c}19 \\
(51 \%)\end{array}$ \\
\hline Livelihoods & $\begin{array}{c}11 \\
(30 \%)\end{array}$ & Restoration & $\begin{array}{c}13 \\
(35 \%)\end{array}$ & Inclusiveness & $\begin{array}{c}13 \\
(35 \%)\end{array}$ & $\begin{array}{l}\text { Research and } \\
\text { Development, } \\
\text { including } \\
\text { commercializat } \\
\text { ion }\end{array}$ & $\begin{array}{c}20 \\
(54 \%)\end{array}$ & $\begin{array}{l}\text { Law and policy } \\
\text { links e.g. } \\
\text { UNCLOS/ } \\
\text { SDGs }\end{array}$ & $\begin{array}{c}16 \\
(43 \%)\end{array}$ \\
\hline \multirow[t]{7}{*}{$\begin{array}{l}\text { Diversification/ } \\
\text { Maritime } \\
\text { clusters }\end{array}$} & $\begin{array}{c}10 \\
(27 \%)\end{array}$ & Protection & $\begin{array}{c}13 \\
(35 \%)\end{array}$ & Equity & $\begin{array}{c}13 \\
(35 \%)\end{array}$ & $\begin{array}{l}\text { Private sector } \\
\text { involvement } \\
\text { (e.g. PPPs) }\end{array}$ & $\begin{array}{c}14 \\
(38 \%)\end{array}$ & $\begin{array}{l}\text { Ecosystem } \\
\text { services } \\
\text { valuation or } \\
\text { payment }\end{array}$ & $\begin{array}{c}15 \\
(41 \%)\end{array}$ \\
\hline & & $\begin{array}{l}\text { Maintaining } \\
\text { environmental } \\
\text { health }\end{array}$ & $\begin{array}{c}9 \\
(24 \%)\end{array}$ & Wellbeing & $\begin{array}{c}10 \\
(27 \%)\end{array}$ & $\begin{array}{l}\text { Innovative } \\
\text { financing e.g. } \\
\text { incentives or } \\
\text { taxes }\end{array}$ & $\begin{array}{c}15 \\
(40 \%)\end{array}$ & $\begin{array}{l}\text { Accounting/ } \\
\text { valuation of } \\
\text { ocean industries }\end{array}$ & $\begin{array}{c}16 \\
(43 \%)\end{array}$ \\
\hline & & & & Social license & $\begin{array}{c}6 \\
(16 \%)\end{array}$ & Data sharing & $\begin{array}{c}12 \\
(32 \%)\end{array}$ & $\begin{array}{l}\text { Stakeholder } \\
\text { engagement }\end{array}$ & $\begin{array}{c}16 \\
(43 \%)\end{array}$ \\
\hline & & & & & & & & $\begin{array}{l}\text { Ecosystem } \\
\text { Based } \\
\text { Management } \\
(\text { EBM }) \\
\end{array}$ & $\begin{array}{c}13 \\
(35 \%)\end{array}$ \\
\hline & & & & & & & & $\begin{array}{l}\text { Monitoring and } \\
\text { reporting }\end{array}$ & $\begin{array}{c}12 \\
(32 \%)\end{array}$ \\
\hline & & & & & & & & $\begin{array}{l}\text { Marine } \\
\text { Protected Areas } \\
\text { (MPAs) }\end{array}$ & $\begin{array}{c}10 \\
(27 \%)\end{array}$ \\
\hline & & & & & & & & $\begin{array}{l}\text { Integrated } \\
\text { Coastal } \\
\text { Management } \\
(\mathrm{ICM})\end{array}$ & $\begin{array}{c}8 \\
(22 \%)\end{array}$ \\
\hline
\end{tabular}


Table 4 - Summary of the key findings of the conceptual analysis of the Blue Economy

\begin{tabular}{|c|c|c|c|c|}
\hline & $\begin{array}{l}\text { Oceans as natural } \\
\text { capital }\end{array}$ & $\begin{array}{l}\text { Oceans as } \\
\text { livelihoods }\end{array}$ & $\begin{array}{l}\text { Oceans as good } \\
\text { business }\end{array}$ & $\begin{array}{l}\text { Oceans as a driver } \\
\text { of innovation }\end{array}$ \\
\hline $\begin{array}{l}\text { Primary } \\
\text { objectives }\end{array}$ & $\begin{array}{l}\text { Ecosystem } \\
\text { protection and/or } \\
\text { restoration }\end{array}$ & $\begin{array}{l}\text { Poverty alleviation } \\
\text { and food security }\end{array}$ & $\begin{array}{l}\text { Economic growth } \\
\text { and employment }\end{array}$ & $\begin{array}{l}\text { Technological or } \\
\text { technical advances }\end{array}$ \\
\hline Actors & $\begin{array}{l}\text { Conservation } \\
\text { agencies/NGOs }\end{array}$ & $\begin{array}{l}\text { Development } \\
\text { agencies, SIDS, } \\
\text { Small Scale Fishers }\end{array}$ & $\begin{array}{l}\text { Industry, larger } \\
\text { global economies } \\
\text { (EU, OECD, China } \\
\text { etc.) }\end{array}$ & $\begin{array}{l}\text { Academic institutes, } \\
\text { industry and } \\
\text { Governments }\end{array}$ \\
\hline Sectors & $\begin{array}{l}\text { Carbon intensive } \\
\text { industries (e.g. oil } \\
\text { and gas) and deep } \\
\text { sea mining excluded. } \\
\text { Focus on economic } \\
\text { benefits from } \\
\text { conservation - e.g. } \\
\text { eco-tourism and } \\
\text { MPAs, Payment for } \\
\text { Ecosystem Services, } \\
\text { Blue Carbon etc. }\end{array}$ & $\begin{array}{l}\text { Primary focus on } \\
\text { small scale } \\
\text { fisheries/eco-tourism } \\
\text { with aspirations for } \\
\text { diversification, } \\
\text { especially } \\
\text { aquaculture. } \\
\text { Precautionary } \\
\text { approach to deep sea } \\
\text { mining. }\end{array}$ & $\begin{array}{l}\text { All sectors included } \\
\text { but primary focus on } \\
\text { large multi-national } \\
\text { corporations and } \\
\text { sectors - shipping, } \\
\text { oil and gas, } \\
\text { renewables. }\end{array}$ & $\begin{array}{l}\text { All sectors but } \\
\text { particularly } \\
\text { emerging industries } \\
\text { like renewables, } \\
\text { biotechnology and } \\
\text { deep sea mining. }\end{array}$ \\
\hline Scale & $\begin{array}{l}\text { All scales (including } \\
\text { ecosystem scale) }\end{array}$ & $\begin{array}{l}\text { Small scale, locally } \\
\text { based }\end{array}$ & $\begin{array}{l}\text { Global/regional and } \\
\text { national }\end{array}$ & $\begin{array}{l}\text { Sub-national - } \\
\text { districts or } \\
\text { provinces }\end{array}$ \\
\hline Tools & $\begin{array}{l}\text { Marine Protected } \\
\text { Areas (MPAs), } \\
\text { Ecosystem Based } \\
\text { Management } \\
\text { (EBM), MSP, } \\
\text { valuation of } \\
\text { ecosystem services }\end{array}$ & $\begin{array}{l}\text { Community } \\
\text { managed } \\
\text { fisheries/MPAs, } \\
\text { MSP, EBM, } \\
\text { valuation of } \\
\text { ecosystem services }\end{array}$ & $\begin{array}{l}\text { MSP, economic } \\
\text { valuation studies, } \\
\text { targeted investment } \\
\text { and growth } \\
\text { strategies. }\end{array}$ & $\begin{array}{l}\text { Innovation } \\
\text { hubs/research } \\
\text { institutes, } \\
\text { innovation } \\
\text { 'challenges' or } \\
\text { competitions, } \\
\text { investment/ } \\
\text { financing strategies. }\end{array}$ \\
\hline
\end{tabular}




\section{Blue Economy}

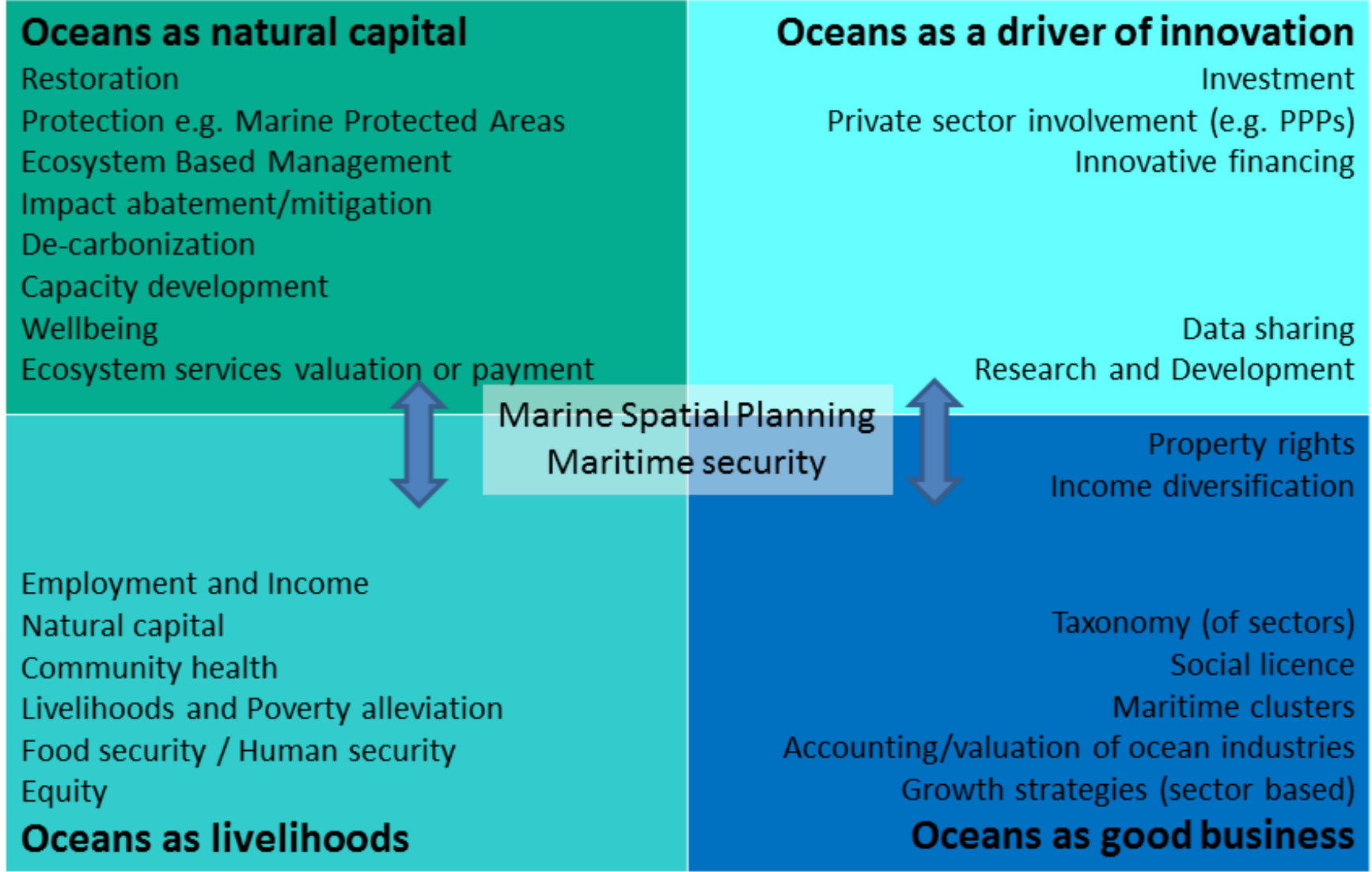

Figure 1. A Blue Economy matrix illustrating related terms and concepts 